\title{
COLLABORATION IN SMART SERVICES - THE RIGHT WAY TO GO?
}

\section{Lucie Kanovska}

Institute of Management, Faculty of Business and Management, Brno University of Technology, Kolejní 2906/4, Brno, Czech Republic E-mail: kanovska@fbm.vutbr.cz

\begin{abstract}
Many current manufacturers provide not only tangible products to their customers, but also services which are accompanying their products. Moreover, manufacturers add smart services to their service offerings. Applying the change toward smart services is not easy, especially in SMEs where many of businesses struggle with lack of money, insufficient digital technologies or unskilled employees. The aim of the study mentioned in this paper explores current situation in SMEs and their attitudes related to collaboration with other subjects on their markets. To address the research objective, a qualitative multi-case study was conducted among seven Czech electrotechnical SMEs, which have already started with smart service development. The findings can indicate two approaches of collaboration based mostly on the owners' enthusiasm for smart services, management's age and the length of running their business. The study is unique in highlighting the problems of smart services in SMEs in the Czech Republic, where the industrial sector is still dominant in comparison to other European countries.
\end{abstract}

Keywords: collaboration, servitization, smart services, SMEs, electrotechnical manufacturers.

JEL Classification: L63.

\section{Introduction}

In recent years, manufacturers have begun to offer products with services in inseparable formats to gain a competitive advantage for surviving in the current markets. Therefore, many current manufacturers provide not only tangible products to their customers, but also services which are accompanying their products such as training, delivery, and after sale services. The process termed servitization was first recognized in the mid-80s and meant general transformation towards a service orientation among manufacturing companies. The term servitization has been used in both academia and practice to capture this phenomenon in which manufacturing companies provide services as an important strategy (Vandermerwe \& Rada, 1988).

Nowadays, manufacturers also add smart services to their service offerings. Smart services can be seen as one of the enablers of servitization (Grubic \& Peppard, 2016; Neu \& Brown, 2008; Oliva \& Kallenberg, 2003). Smart service solutions in manufacturing companies include both hardware solutions as well as an essential service component. Smart services provide many benefits for both manufacturing companies as service providers as well as for their customers. Moreover, smart services in manufacturing companies can improve value creation and profitability for both the business and customers. Applying the change toward smart services is not easy, especially in SMEs (small and mediumsized enterprises) where many businesses struggle with lack of money, insufficient digital technologies, or unskilled employees. There is an expectation that some kind of collaborations based on digital services can help companies to succeed better.

Service transformation has been studied in some researches, but not so many studies have focused on the impact of digitalization of industrial services. To fill the gap, the study presented in this paper explores current situation in Czech electrotechnical SMEs and their attitudes to collaborate with other subjects on their markets. To address the research objective, a qualitative multi-case study was conducted among seven Czech electrotechnical SMEs, which have already started with smart service development. The aim of the paper is to explore current situation in SMEs and their attitudes related to collaboration with other subjects on their markets. According to the findings in the paper, the first idea related to collaboration could be seen in two possible approaches for collaboration with other subjects 
and competitors, which are based mostly on the owners' enthusiasm for smart services, management's age and how long has the business operated. The study is unique in highlighting the problems of smart services in SMEs in the Czech Republic, where the industrial sector is still dominant in comparison to other European countries. Moreover, it investigates the approaches for collaboration in SMEs.

\section{Theoretical background}

\subsection{Service offering in manufacturing companies}

The manufacturing companies now seek more service-led growth to secure their position and to expand to competitive markets (Reinartz \& Ulaga, 2008; Ostrom, Parasuraman, Bowen, Patricio, \& Voss, 2015). Instead of only innovating the products, the companies are investing in service differentiation. Consequently, instead of services being add-ons to the product, services become the center of the total offering, with products as addons to the services (Gebauer, Gustafsson, \& Witell, 2011). The use of service differentiation in manufacturing takes advantage of the strategic, financial and marketing opportunities. Services lead to the creation of value based on the competency of the company and the customer (Matthyssens, Vandenbempt, \& Berghman, 2006; Vargo \& Lusch, 2008), which leads to resources that are unique and hard to imitate (Wernerfelt, 1984). Financial opportunities include additional service revenues throughout the product lifecycle (Wise \& Baumgartner, 1999). Marketing opportunities involve using services to augment the product offering and increasing the quality of the customer interaction (Mathieu, 2001). Similarly, Davies, Brady, and Hobday (2007) indicates that services provide a more constant income, higher profit margins and require less asset allocation than manufacturing.

The process, termed 'servitization', was first mentioned by Vandermerwe and Rada (1988). Servitization means a transformation of manufacturers to solution providers by adding value to core products through services (Baines et al., 2017; Wise \& Baumgartner, 1999). Due to servitization, the focus shifts more and more from a product-centered focus towards the service component (Brax \& Jonsson, 2009; Gronroos, 1990). Services and integrated solution can help to gain new sources of competitive advantage and value generation (e.g. Brax \& Jonsson, 2009; Oliva \& Kallenberg, 2003; Wise \& Baumgartner,
1999). Also, service revenues are on the rise in manufacturing companies. In 1990, it was $8.9 \%$ and in 2005 42.2\% (Fang, Palmatier, \& Steenkamp, 2008).

\subsection{Smart services}

Allmendinger and Lombreglia (2005) mentioned that "Soon, it will not be enough for a company to offer services; it will have to provide "smart services'." Many authors often describe smart services as one of the enablers of servitization (e.g. Grubic \& Peppard, 2016; Neu \& Brown, 2008; Oliva \& Kallenberg, 2003). What are smart services in manufacturing exactly?

Smart services use many opposing definitions and terminologies (Klein, 2017), such as 'teleservice' (Borgmeier, 2002; Küssel, Liestmann, Spiess, \& Stich, 2000), 'tele-maintenance' (Garcia, Guyennet, Lapayre, \& Zerhouni, 2004), 'telematics' (Chatterjee, Greenberg, Jones, Kaas, \& Wojcik, 2001), "e-service' (Rowley, 2006), 'e-maintenance' (Levrat, Iung, \& Crespo Marquez, 2008) or some variations, combinations or adaptions using the term 'remote', such as 'RRDM (Remote Repair, Diagnostics and Maintenance)' (Biehl, Prater, \& McIntyre, 2004). According to Klein (2017), the term 'smart service' has gained popularity more recently. Klein $(2017$, p. 8 ) describes smart services as: "Smart services are technologically-mediated services actively delivered by the provider through accessing a remote asset and exchanging data through built-in control and/or feedback devices." Beverungen, Matzner, and Janiesch (2017) describe smart service as the application of specialized competences, through deeds, processes, and performances that are enabled by smart products.

Smart services offer a lot of benefits for manufacturing companies as service providers and also for their customers. Services are more competitive, offer new sources of revenue, higher margins, and considerable cost savings (Küssel et al., 2000). In addition to monetary benefits, smart services can offer a variety of non-monetary benefits. Possible non-monetary benefits could be the opportunity to learn from customers, establishing a basis for research and development, sales or marketing activities (Laine, Paranko, \& Suomala, 2010). Accordingly, they are gaining a considerable strategic importance in B2B and B2C contexts (Wünderlich et al., 2015). Porter and Heppelmann (2014) summarize the importance of smart services: "[They] offer exponentially expanding opportunities for new 
functionality, far greater reliability, much higher product utilization, and capabilities that cut across and transcend traditional product boundaries". Benchmarks show that companies, which deliver smart services, get more than $50 \%$ of revenue and $60 \%$ of margins from services than from product sales (Allmendinger \& Lombreglia, 2005).

Customers can gain many benefits from smart services, such as "the value of removing unpleasant surprises from their lives" (Allmendinger \& Lombreglia, 2005, p. 132). The benefits could be realized in the form of reduction of machine downtimes, optimized scheduling of maintenance, more safety, improved information flow and transparency as well as a reduction of labor costs and creation of a better work environment (Lee, Kao, \& Yang, 2014). Many manufacturing companies increasingly adopt these novel smart services, because of their significant advantages.

\subsection{Collaboration}

Gebauer, Paiolaand, and Saccani (2013) notes that technological innovation emphasizes the increasing importance of accessing resources out of firms' boundaries, since the impressive expansion of digital technologies in business put many companies at risk and increases uncertainty (Gimpel \& Röslinger, 2015).

Lack of digital capabilities is often seen as an important driver for companies to take the decision to start with collaboration. According to Rickne (2006), relationships with well-established companies provide IT firms with exciting market and customer information. Therefore, an increasing amount of multiorganizational collaboration based on digital services that transform traditional business operations and make cooperation a key success factor can be expected (Pagani \& Aiello, 2013).

As mentioned by Ritala and HurmelinnaLaukkanen (2009), coopetition is usually presented as a positive-sum game where enlarged "business pie" triggers competitive moves to appropriate value generated together with rivals. Prior to academic acknowledgement, the coopetition term itself has been invented by practitioners to reflect a complex business reality of firm's mutual interdependence, environment pressures, and customer driver actions (Bouncken \& Kraus, 2013). As Czakon (2010) notes competitive strategies have been particularly in focus in the high-tech industry.

The idea of coopetition strategy has been presented in the management literature meaning of a synchronized action of various actors within a value network, involving rivals, customers, suppliers and complementors (Brandenburger \& Nalebuff, 1996). A narrow view of coopetition restricts the scope of scrutiny on others (Bengtsson \& Kock, 2000). Coopetition appears here as a complex and paradoxical phenomenon (Raza-Ullah, Bengtsson, \& Kock, 2014) entailing two opposing logics of interaction: collaboration aimed at value creation, and competition aimed at value appropriation.

Companies can improve their financial, market or innovation performance by collaborating with competitors (Le Roy \& Czakon, 2016). Nevertheless, firms could accidentally strengthen their rival, transfer critical knowledge or misappropriate value (Fernandez, Le Roy, \& Gnyawali, 2014).

Some authors perceive that a coopetition strategy arises based on specific exogenous pressures, i.e. managers would otherwise not have adopted it (Czakon, Mucha-Kus, \& Rogalski, 2014). Earlier literature on high-tech firms' coopetition recommends that technology convergence, short product life-cycle and high $R \& D$ costs could be increasing the probability of adopting this strategy (Gnyawali \& Park, 2009). Furthermore, as Ritala (2012) states the intensity of the competition in high-technology industries has been found to favor coopetition adoption.

Both endogenous and exogenous factors persuade high-tech firms' managers to start with collaboration. According to Czakon et al. (2014), the thoughtful perspective on coopetition adoption looks at the motivations underlying its adoption, typically focused on endogenous factors such as increasing the size of the market, efficiencies in resource utilization, and improvement of a firms' competitive position (Ritala, 2012). Operating on high-tech industries positions remarkable challenges, mostly related to resource constraints (Gnyawali \& Park, 2009). There are two distinct logics: complementarity and similarity. The complementarity logic refers to combining resources in order to gain a more comprehensive, synergistic set coupled with economics of scope (Gnyawali \& Park, 2009). Contrariwise, the similarity logic refers to scale economics, increased bargaining power and the ability to operate together of involved forms.

\section{Methodology}

Existing research in the field of smart services is mostly focused on case studies (e.g. Grubic, 2014; 
Wünderlich et al., 2015). Literature frequently describes mostly generic process steps on how to operate in a smart service environment (Brax \& Jonsson, 2009). Theoretical understanding of smart services is still almost the beginning and is not as advanced as practical knowledge about it. Subsequently, there is a lack of knowledge about how smart services are used in praxis by manufacturing companies (Grubic \& Peppard, 2016). As Wünderlich et al. (2015) recapitulate, "Despite the accelerating development of these smart services, academic research is still in its infancy. We see the need to further explore the effect that smart service has on organizations, customers and the evolving service landscape" (Wünderlich et al., 2015, p. 443). In addition, Dachs et al. (2014) noticed that the majority of existing research is based on case studies (e.g. Brax \& Jonsson, 2009; Dachs et al., 2014; Davies et al., 2007; Neu \& Brown, 2008; Oliva \& Kallenberg, 2003) and conclude that these case studies should be accompanied by quantitative, survey-based analysis across a sample of manufacturing companies (Dachs et al., 2014; Gebauer \& Kowalkowski, 2012; Neu \& Brown, 2008).

To learn more about smart services in manufacturing, a qualitative research was conducted as a multi-case study among seven SMEs electrotechnical companies, South Moravian Region. The research investigated how smart services are provided by current manufacturing SMEs. The in-depth interviews explored following aspects: type of smart products and smart services, the length and way of smart service provision, customer perception of smart services, the reasons for starting with smart service provision, the benefits gained from smart services, barriers connected to smart service provision, gathering and using the data gained from smart services, specifics of Czech industrial market, collaboration with other firms and "learnings" for other firms which want to start with smart services.

The multi-case approach provided analytical benefits over a single-case by enabling comparison and contrast of the results to find the distinction of case specific findings as well as some general phenomena. The part of the study focusing on collaborations with other firms was used for the purpose of this paper.

\subsection{Context of the research}

Manufacturers have begun to offer products with services to gain a competitive advantage in recent years. Manufacturing companies have started to invest into servitization by delivering smart services, which enable data exchange between their customers and service provider by connected product-service systems.

All the case companies in the qualitative research were SMEs from the same industry electrotechnical producers. They operate in one industry, but they provide a wide range of products and services to their customers with varying degrees of service orientation. All case companies have been implementing smart services to their companies in different level and range. Case companies mostly provided the following smart services: remote monitoring, control and diagnostics, remote repairs, preventive and predictive maintenance.

The different level and wide range of smart services provides valuable insights into smart services in SMEs in different contexts. It was the aim to select companies from the same industry, but in different maturity phases in their service transformation journey.

The case companies for qualitative research were selected based on purposive sampling (Eisenhardt \& Graebner, 2007). The details of the case companies are described in Table 1.

Table 1. Case company description (source: author)

\begin{tabular}{|c|l|c|c|}
\hline Firm & Respondents & $\begin{array}{c}\text { Number } \\
\text { of em- } \\
\text { ployees }\end{array}$ & $\begin{array}{c}\text { The length of } \\
\text { smart service } \\
\text { provision in } \\
\text { years }\end{array}$ \\
\hline A & Owner & 15 & 1 \\
\hline B & $\begin{array}{l}\text { Product } \\
\text { manager }\end{array}$ & 50 & 1 \\
\hline C & Owner & 10 & 2 \\
\hline D & Owner & 4 & 2 \\
\hline E & Owner & 25 & 2 \\
\hline F & Owner & 148 & 2 \\
\hline G & $\begin{array}{l}\text { Product } \\
\text { Manager }\end{array}$ & 170 & More than 2 \\
\hline
\end{tabular}

Three companies were found as the members of Electrotechnical Association of the Czech Republic (https://www.electroindustry.cz/). Four companies providing smart services were detected from the previous research, which was held in sixty electrotechnical SMEs companies in the Czech Republic, South Moravian Region (CZNACE 26 and CZ-NACE 27). The respondents participating in the research were directors or managers of companies producing electrical engineering equipment in the Czech Republic. 
The data were collected from February to November 2014. The research (part of which focused on services in manufacturing) contributed to the existing knowledge base by offering insights into service offering of manufacturing companies, especially electrotechnical ones. The research was important not only to learn know more about the current situation of service offering in electrotechnical companies but was also crucial for searching possible companies which provide also smart services for their customers.

\subsection{Data collection}

The qualitative research consists of in-depth interviews with owners or with experienced senior managers in the selected organizations. The interviews were carried out from April 2017 to January 2018. Each interview lasted from 50 to 100 minutes and was performed on site, which gave a chance to tour each company and get a sense of the work environment. The sample size matches the recommendations for exploratory research (Corbin, Strauss, A., \& Strauss, A. L., 2014). To enable the relaxed communication, the informants' anonymity was guaranteed through the assurance that the results would be released without any identifying information. All interviews were recorded and transcribed. After selecting the case companies, semi-structured interviews with predefined themes were conducted. The interview consisted of open-ended questions, which were based on the literature review. All interviews were conducted face-toface.

\subsection{Data analysis}

The data analysis followed an abductive analysis process, where the understanding of the phenomenon based on the study of literature laid the foundation for early interviews, which then used evolving themes to track important issues as the interviews progressed and the understanding of smart services in the real-life setting increased (Dubois \& Gadde, 2014). Open coding was used to organize the data and convert them to discrete thematic blocks. As qualitative case research is sensitive to researchers' subjective interpretations, some checks and peer debriefing to reduce researcher bias were conducted to increase the objectivity of the study. A rich set of direct interview quotations to demonstrate interpretations was added to support the transparency and conformability of the findings.

\section{Findings}

The analysis of the section related to possible collaboration with other firms identified one research question (RQ), which was formulated in the following statement: RQ: How do electrotechnical companies providing smart services collaborate with other subjects on the market? To address this RQ, the approach employed in data collection was structured in four related questions: a) Do you (plan to) collaborate with other subjects on the market? b) If yes, which kind of subjects are (will be) your collaborators? c) Why do you collaborate with other subjects? d) What is the description of respondents? All four questions are discussed below. Following quotes illustrate the findings.

a) Do you (plan to) collaborate with other subjects on the market?

Six case companies already collaborate with other subjects on the market. Only one respondent does not cooperate with any subject on the market.

"We are definitely open to collaboration!"

"During our regular meetings held by Electrotechnical Association we share our experience and know-how, also in the field of digitalization. "

„We cooperate with students from high schools and universities. They can get some practical experience as well as work on their final and diploma theses. Students are sometimes very creative, they think "out of the box" and they are quite eager to work in our company. Moreover, they are cheaper for us."

„We are also able to cooperate with competitors, in which situation we use the agreement about our partnership related to the development of new SW. This mutual cooperation can help all parties involved to move towards the international market."

\footnotetext{
b) If yes, which kind of subjects are (will be) your collaborators?

Respondents from six case studies collaborate with the following collaborators:

- Customers (4x)

- Competitors (3x)

- Complementors (3x)

- External suppliers of HW and SW (3x)

- Students from High schools and Universities $(2 \mathrm{x})$

- Members of Electrotechnical Association $(2 \mathrm{x})$

$-\quad$ Start-up (1x)
} 
The numbers in the brackets shows the number of respondents who mentioned the particular collaborators.

„We do not cooperate with our competitors, but we collaborate with the suppliers of SW. This supplier is small start-up working as a part of Brno University of Technology). We are responsible for our R\&D, however, we do not share its outputs with public. We inform only our customers about our research outputs."

„Territorial servitization is trendy today. Companies want to be connected within the regions. They want to be the suppliers of an international company which could help them to enter foreign markets."

\section{c) Why do you collaborate with other subjects?}

Main reasons, describing why case companies collaborate with other companies, as mentioned by the respondents:

- experience and know-how sharing, also in the field of digitalization

- easier way to international markets

- more positive customer perception of a company, also in the field of digitalization

- lower costs and new ideas from students cooperating with the case companies

- better international market division

- better and wider service offering and its improvement

- mutual cooperation to find and solve possible problems

- better cooperation in regions to find out possible global corporation to get to international markets

„We cooperate with our customers and develop new products and services together in accordance with their plans and needs. This collaboration helps us to decrease the amount of possible problems. "

„We outsource services from one start-up to provide new SW. R\&D is provided by external companies."

\section{d) What is the description of respondents?}

The last part of findings shows the respondents and their short description based on five criteria - company history in years, age of respondents (mostly owners of case companies), attitude to smart service provision, collaboration with subjects on the market and collaboration with the competitors. The information describing the respondents is mentioned below in the Table 2 and Table 3 (with the focus on collaboration).

Table 2. Description of respondents from case companies (source: author)

\begin{tabular}{|c|l|c|l|}
\hline Firm & $\begin{array}{c}\text { Company } \\
\text { history }\end{array}$ & $\begin{array}{c}\text { Age of } \\
\text { respondent } \\
\text { S }\end{array}$ & $\begin{array}{c}\text { Respondents' } \\
\text { attitudes to } \\
\text { smart service } \\
\text { provision }\end{array}$ \\
\hline A & $\begin{array}{l}\text { more than } \\
5 \text { years }\end{array}$ & 45 & less active \\
\hline B & $\begin{array}{l}\text { more than } \\
5 \text { years }\end{array}$ & 50 & less active \\
\hline C & $\begin{array}{l}\text { more than } \\
5 \text { years }\end{array}$ & 42 & less active \\
\hline D & $\begin{array}{l}\text { less than } 2 \\
\text { years }\end{array}$ & 27 & very active \\
\hline E & $\begin{array}{l}\text { less than } 2 \\
\text { years }\end{array}$ & 28 & very active \\
\hline F & $\begin{array}{l}\text { more than } \\
5 \text { years }\end{array}$ & 60 & very active \\
\hline G & $\begin{array}{l}\text { more than } \\
5 \text { years }\end{array}$ & 50 & very active \\
\hline
\end{tabular}

Table 3. Description of respondents from case companies focused on collaboration (source: author)

\begin{tabular}{|c|c|c|}
\hline Firm & $\begin{array}{c}\text { Collaboration with } \\
\text { subjects on the } \\
\text { market }\end{array}$ & $\begin{array}{c}\text { Collaboration with } \\
\text { the competitors }\end{array}$ \\
\hline A & Yes & Yes \\
\hline B & Yes & Yes \\
\hline C & No & No \\
\hline D & Yes & Yes \\
\hline E & Yes & Yes \\
\hline F & Yes & Yes \\
\hline G & Yes & Yes \\
\hline
\end{tabular}

The findings indicate that six companies collaborate with other subjects on the market and that three of them collaborate even with their competitors. Case companies collaborating with competitors can be characterized as very active and full of enthusiasm for providing smart services, and then two of them are young companies with young owners, who perceive smart services as crucial factor of their business. Furthermore, they cannot imagine not providing smart services to their customers at all. The first idea generated from findings could be that there are two possible approaches of collaboration with other subjects and competitors, which are based mostly on the owners' enthusiasm for smart services, management's age, and how long the 
business has operated. However, the limited number of cases discourages a consistent generalization of the findings achieved so far, that will have to be confirmed by further investigations.

To sum up, the analysis revealed four basic questions related to possible collaboration with other subjects on the market in current electrotechnical SMEs.

\section{Discussion}

The focus of this research has been an exploration of aspects related to possible collaboration with other subjects on the market. The qualitative research was held among electrotechnical companies in the Czech Republic, South Moravian Region. A research question was formulated in this paper to discover how companies collaborate with other subjects. To answer the research question, the case studies investigated the situation in seven firms.

\subsection{Theoretical Implications}

Smart services based on smart products discussed in the paper are a very innovative topic, which is quite new in the research field and still open to new investigations. As Gebauer et al. (2013) mentioned, technological innovations emphasize the importance of access to resources out of firms' boundaries. According to the research mentioned in this paper, six case companies (from seven possible) collaborate with other subjects on the market. The most important collaborators and their motivations to cooperate by the companies studied are: customers $(4 \mathrm{x})$ (for mutual cooperation in product development, solving problems and service offerings, experience and know-how sharing, also in the field of digitalization and improvement of customer perception), competitors (3x) (experience and knowhow sharing, also in the field of digitalization and better international market division), complementors $(3 \mathrm{x})$, external suppliers of $H W$ and $S W(3 \mathrm{x})$. The findings from the case studies are in line with Brandenburger and Nalebuff (1996), who said that coopetition strategy involve rivals, customers, suppliers and complementors. Also, Tomaskova (2009) mentioned that all methods included in her research for measuring market orientation involved only a few components of market orientation, the most often mentioned components are orientation on customers, orientation on competition and interfunctional cooperation. The other components of market orientation are usually missed out.
Also, three case companies collaborate with competitors. Ritala and Hurmelinna-Laukkanen (2009) stated that coopetition is usually presented as a positive-sum game where enlarged "business pie" triggers competitive moves to appropriate value generated together with rivals. The respondents who are willing to cooperate with competitors are mostly new companies with young owners full of enthusiasm for smart services. Additionally, smart services are well established in their service offering and are seen as a necessity. As Le Roy and Czakon (2016) noticed, firms can improve their financial, market or innovation performance by collaborating with competitors. Consequently, the management decision to engage into collaboration with competitors appears as complex and challenging.

According to these findings, some possible schemes could be created. The first scheme could describe the most important collaborators with other subjects, including competitors. The second scheme could describe the most possible reasons for collaboration. These schemes could provide a better insight into the problems of possible collaborators among small and medium companies. The schemes are not presented in this paper as they would need more research. Profitable collaboration should help both sides. Managers often seek to strengthen their position to increase their market share and possibly become the biggest market players through joining forces, which could help them to survive in today's fierce markets.

\subsection{Managerial Implications}

The findings illustrate the impact of collaboration with other subjects, including competitors, on the market in electrotechnical companies. Competitors are likely to possess similar capabilities or knowledge as they face the same challenges in the same business context (Ritala \& HurmelinnaLaukkanen, 2009). As Gnyawali and Park (2009) noted, firms actively prospecting knowledge are claimed to be more likely to enter coopetition.

According to the findings, the first idea related to collaboration could be seen in two possible approaches for collaboration with other subjects and competitors, which are based mostly on the owners' enthusiasm for smart services, management's age and how long has the business operated. However, the limited number of cases discourages a consistent generalization of the findings achieved so far. Probably not only new companies with young owners can be open for smart service provision. Also, one company 
included in the research was not young and its owner was in his sixties. However, he was very enthusiastic about smart service provisions. Smart services are not only about the age of the owners or top managers, but mostly about their passion. If companies are open and convinced about smart services, they can start designing strategies and provide services to their customers.

Nevertheless, all case companies from the qualitative research agreed that smart services are the future of manufacturing. In some industries, smart services are still perceived as a possible competitive advantage, but in a couple of years, smart services will be a necessity. It is likely that sustainable competitive advantage may be achieved through complex combinations of interconnected products and services found within manufacturers, customers and intermediaries, if needed.

\section{Conclusions}

Smart services based on smart product presented are an emerging topic, which is still not widely discussed. Therefore, it is crucial to focus on this area. The paper explores current situation in SMEs, which provide smart services to their clients. It also analyses their attitudes related to collaboration with other subjects on the markets. To address the research objective, a qualitative multi-case study was conducted among seven Czech electrotechnical SMEs, which have already started providing smart service development.

The findings revealed that the companies collaborate with other subjects on the market for different reasons. They definitely perceive the benefits of collaboration. To sum up, collaboration in smart services is the right way to go.

This paper tried to contribute to the understanding of the role of possible mutual collaboration in the current manufacturing companies. Based on the case studies findings, the first implications for practice and theory are drawn. However, the study presented in this paper is still in the initial phase. The number of cases limitates a consistent generalization of achieved findings. The findings will be confirmed by further investigations.

Future quantitative research of smart services will be prepared during the second half of this year. The research will be held in small and medium manufacturers and will be focused on smart services. The aim will be to verify the findings from the qualitative research described in this paper. Future studies should investigate further how and why to collaborate with other subjects, which endogenous and exogenous factors can influence collaboration, and finally, prepare some scheme of this cooperation.

\section{Acknowledgements}

Eva Tomaskova contributed in the research, which was held in sixty electrotechnical SMEs companies in the Czech Republic, South Moravian Region in 2014.

\section{Disclosure Statement}

I declare that I do not have any competing financial, professional or personal interests from other parties.

\section{References}

Allmendinger, G., \& Lombreglia, R. (2005). Four strategies for the age of smart services. Harvard Business Review, 83(10), 131.

Baines, T., Ziaee Bigdeli, A., Bustinza, O. F., Shi, V. G., Baldwin, J., \& Ridgway, K. (2017). Servitization: revisiting the state-of-the-art and research priorities. International Journal of Operations \& Production Management, 37(2), 256-278.

https://doi.org/10.1108/IJOPM-06-2015-0312

Bengtsson, M., \& Kock, S. (2000). "Coopetition" in business Networks - to cooperate and compete simultaneously. Industrial Marketing Management, 29(5), 411-426. https://doi.org/10.1016/S0019-8501(99)00067-X

Beverungen, D., Matzner, M., \& Janiesch, C. (2017). Information systems for smart services. Information Systems and e-Business Management, 15(4), 781-787. https://doi.org/10.1007/s10257-017-0365-8

Biehl, M., Prater, E., \& McIntyre, J. R. (2004). Remote repair, diagnostics, and maintenance. Communications of the ACM, 47(11), 100-106. https://doi.org/10.1145/1029496.1029501

Borgmeier, A. (2002). Schlußbetrachtung. In Teleservice im Maschinen- und Anlagenbau (pp. 209-217). Deutscher Universitätsverlag, Wiesbaden. https://doi.org/10.1007/978-3-322-81064-9

Bouncken, R. B., \& Kraus, S. (2013). Innovation in knowledge-intensive industries: The double-edged sword of coopetition. Journal of Business Research, 66(10), 2060-2070 https://doi.org/10.1016/j.jbusres.2013.02.032

Brandenburger, A., \& Nalebuff, B. (1996). Co-opetition: a revolutionary mindset that combines competition and cooperation in the marketplace: the game theory strategy that's changing the game of business. Edições Harper-Collins.

Brax, S. A., \& Jonsson, K. (2009). Developing integrated solution offerings for remote diagnostics: A comparative case study of two manufacturers. International Journal of Operations \& Production Management, 29(5), 539-560. https://doi.org/10.1108/01443570910953621 
Chatterjee, A., Greenberg, J., Jones, M., Kaas, H. W., \& Wojcik, P. (2001). Telematics: decision time for detroit. London Business School Review, 12(2), 21-38. https://doi.org/10.1111/1467-8616.00172

Corbin, J., Strauss, A., \& Strauss, A. L. (2014). Basics of qualitative research. Sage. $456 \mathrm{p}$.

Czakon, W. (2010). Emerging coopetition: An empirical investigation of coopetition as inter-organizational relationship instability. In S. Yami, S. Castaldo \& G. Battista Dagnino (Eds.), Coopetition: Winning strategies for the 21st century (pp. 58-73). https://doi.org/10.4337/9781849807241.00011

Czakon, W., Mucha-Kus, K., \& Rogalski, M. (2014). Coopetition research landscape-a systematic literature review 1997-2010. Journal of Economics \& Management, 17, 121.

Dachs, B., Biege, S., Borowiecki, M., Lay, G., Jäger, A., \& Schartinger, D. (2014). Servitisation of European manufacturing: evidence from a large-scale database. The Service Industries Journal, 34(1), 5-23. https://doi.org/10.1080/02642069.2013.776543

Davies, A., Brady, T., \& Hobday, M. (2007). Organizing for solutions: Systems seller vs. systems integrator. Industrial Marketing Management, 36(2), 183-193. https://doi.org/10.1016/j.indmarman.2006.04.009

Dubois, A., \& Gadde, L. E. (2014). "Systematic combining" - A decade later. Journal of Business Research, 67(6): 1277-1284. https://doi.org/10.1016/j.jbusres.2013.03.036

Eisenhardt, K. M., \& Graebner, M. E. (2007). Theory building from cases: Opportunities and challenges. Academy of Management Journal, 50(1), 25-32. https://doi.org/10.5465/amj.2007.24160888

Fang, E., Palmatier, R. W., \& Steenkamp, J. B. E. (2008). Effect of service transition strategies on firm value. Journal of Marketing, 72(5), 1-14. https://doi.org/10.1509/jmkg.72.5.1

Fernandez, A. S., Le Roy, F., \& Gnyawali, D. R. (2014). Sources and management of tension in co-opetition case evidence from telecommunications satellites manufacturing in Europe. Industrial Marketing Management, 43(2), 222-235.

https://doi.org/10.1016/j.indmarman.2013.11.004

Garcia, E., Guyennet, H., Lapayre, J. C., \& Zerhouni, N. (2004). A new industrial cooperative tele-maintenance platform. Computers \& Industrial Engineering, 46(4), 851-864. https://doi.org/10.1016/j.cie.2004.05.019

Gebauer, H., Gustafsson, A., \& Witell, L. (2011). Competitive advantage through service differentiation by manufacturing companies. Journal of Business Research, 64(12), 1270-1280.

https://doi.org/10.1016/j.jbusres.2011.01.015

Gebauer, H., \& Kowalkowski, C. (2012). Customer-focused and service-focused orientation in organizational structures. Journal of Business \& Industrial Marketing, 27(7), 527-537.

https://doi.org/10.1108/08858621211257293

Gebauer, H., Paiola, M., \& Saccani, N. (2013). Characterizing service networks for moving from products to solutions. Industrial Marketing Management, 42(1), 31-46. https://doi.org/10.1016/j.indmarman.2012.11.002

Gimpel, H., \& Röglinger, M. (2015). Digital transformation: changes and chances - insights based on an empirical study. Fraunhofer FIT.

Gnyawali, D. R., \& Park, B. J. R. (2009). Co-opetition and technological innovation in small and medium-sized enterprises: A multilevel conceptual model. Journal of Small Business Management, 47(3), 308-330.

https://doi.org/10.1111/j.1540-627X.2009.00273.x

Gronroos, C. (1990). Relationship approach to marketing in service contexts: The marketing and organizational behavior interface. Journal of Business Research, 20(1), 3-11.

https://doi.org/10.1016/0148-2963(90)90037-E

Grubic, T. (2014). Servitization and remote monitoring technology: A literature review and research agenda. Journal of Manufacturing Technology Management, 25(1), 100-124. https://doi.org/10.1108/JMTM-05-2012-0056

Grubic, T., \& Peppard, J. (2016). Servitized manufacturing firms competing through remote monitoring technology: An exploratory study. Journal of Manufacturing Technology Management, 27(2), 154-184. https://doi.org/10.1108/JMTM-05-2014-0061

Klein, M. M. (2017). Design rules for smart services: Overcoming barriers with rational heuristics (Doctoral dissertation). Universität St. Gallen.

Küssel, R., Liestmann, V., Spiess, M., \& Stich, V. (2000). "TeleService" a customer-oriented and efficient service?. Journal of Materials Processing Technology, 107(1-3), 363-371. https://doi.org/10.1016/S0924-0136(00)00727-5

Laine, T., Paranko, J., \& Suomala, P. (2010). Downstream shift at a machinery manufacturer: the case of the remote technologies. Management Research Review, 33(10), 980-993.

https://doi.org/10.1108/01409171011083987

Le Roy, F., \& Czakon, W. (2016). Managing coopetition: the missing link between strategy and performance. Industrial Marketing Management, 53(1), 3-6. https://doi.org/10.1016/j.indmarman.2015.11.005

Lee, J., Kao, H. A., \& Yang, S. (2014). Service innovation and smart analytics for Industry 4.0 and big data environment. Procedia CIRP, 16, 3-8. https://doi.org/10.1016/j.procir.2014.02.001

Levrat, E., Iung, B., \& Crespo Marquez, A. (2008). E-maintenance: review and conceptual framework. Production Planning \& Control, 19(4), 408-429. https://doi.org/10.1080/09537280802062571

Mathieu, V. (2001). Product services: from a service supporting the product to a service supporting the client. Journal of Business \& Industrial Marketing, 16(1), 39-61. https://doi.org/10.1108/08858620110364873

Matthyssens, P., Vandenbempt, K., \& Berghman, L. (2006). Value innovation in business markets: Breaking the industry recipe. Industrial Marketing Management, 35(6), 751-761. https://doi.org/10.1016/j.indmarman.2005.05.013

Neu, W. A., \& Brown, S. W. (2008). Manufacturers forming successful complex business services: Designing an organization to fit the market. International Journal of Service Industry Management, 19(2), 232-251. https://doi.org/10.1108/09564230810869757

Oliva, R., \& Kallenberg, R. (2003). Managing the transition from products to services. International Journal of Service Industry Management, 14(2), 160-172. https://doi.org/10.1108/09564230310474138

Ostrom, A. L, Parasuraman, A., Bowen, D. E., Patricio, L., \& Voss, C. A. (2015). Service research priorities in a rapidly changing context. Journal of Service Research, 18(2), 127-159.

https://doi.org/10.1177/1094670515576315 
Pagani, G. A., \& Aiello, M. (2013). The power grid as a complex network: A survey. Physica A: Statistical Mechanics and its Applications, 392(11), 2688-2700. https://doi.org/10.1016/j.physa.2013.01.023

Porter, M. E., \& Heppelmann, J. E. (2014). How smart, connected products are transforming competition. Harvard Business Review, 92(11), 64-88.

Raza-Ullah, T., Bengtsson, M., \& Kock, S. (2014). The coopetition paradox and tension in coopetition at multiple levels. Industrial Marketing Management, 43(2), 189-198. https://doi.org/10.1016/j.indmarman.2013.11.001

Reinartz, W., \& Ulaga, W. (2008). How to sell services more profitably. Harvard Business Review, 86(5), 90.

Rickne, A. (2006). Connectivity and performance of sciencebased firms. Small Business Economics, 26(4), 393407. https://doi.org/10.1007/s11187-005-4848-5

Ritala, P. (2012). Coopetition strategy - when is it successful? Empirical evidence on innovation and market performance. British Journal of Management, 23(3), 307-324.

Ritala, P., \& Hurmelinna-Laukkanen, P. (2009). What's in it for me? Creating and appropriating value in innovation-related coopetition. Technovation, 29(12), 819-828.

https://doi.org/10.1016/j.technovation.2009.07.002
Rowley, J. (2006). An analysis of the e-service literature: towards a research agenda. Internet Research, 16(3), 339-359. https://doi.org/10.1108/10662240610673736

Tomaskova, E. (2009). The current methods of measurement of market orientation. European Research Studies, $12(3), 135$.

Vandermerwe, S., \& Rada, J. (1988). Servitization of business: adding value by adding services. European Management Journal, 6(4), 314-324. https://doi.org/10.1016/0263-2373(88)90033-3

Vargo, S. L., \& Lusch, R. F. (2008). Service-dominant logic: continuing the evolution. Journal of the Academy of marketing Science, 36(1), 1-10. https://doi.org/10.1007/s11747-007-0069-6

Wernerfelt, B. (1984). A resource-based view of the firm. Strategic Management Journal, 5(2), 171-180. https://doi.org/10.1002/smj.4250050207

Wise, R., \& Baumgartner, P. (1999). Go downstream. Harvard Business Review, 77.5.

Wünderlich, N. V., Heinonen, K., Ostrom, A. L., Patricio, L., Sousa, R., Voss, C., \& Lemmink, J. G. (2015). "Futurizing" smart service: Implications for service researchers and managers. Journal of Services Marketing, 29(6/7), 442-447.

https://doi.org/10.1108/JSM-01-2015-0040 